\title{
PIK3AP1 wt Allele
}

National Cancer Institute

\section{Source}

National Cancer Institute. PIK3AP1 wt Allele. NCI Thesaurus. Code C147050.

Human PIK3AP1 wild-type allele is located in the vicinity of 10q24.1 and is approximately $127 \mathrm{~kb}$ in length. This allele, which encodes phosphoinositide 3-kinase adapter protein 1, plays a role in B-cell receptor and toll-like receptor signaling. 